\title{
Improved grazing activity of dairy heifers in shaded tropical grasslands
}

\author{
Andréia Cristina Tavares de Mello ${ }^{1}$ Roberta Aparecida Carnevalli ${ }^{* *}$ Luciano Shozo Shiratsuchi $^{2}$ \\ Bruno Carneiro e Pedreira ${ }^{2}$ Luciano Bastos Lopes ${ }^{2}$ Diego Batista Xavier ${ }^{2}$
}

${ }^{1}$ Programa de Pós-graduação, Universidade Federal do Mato Grosso (UFMT), Sinop, MT, Brasil.

${ }^{2}$ Empresa Brasileira de Pesquisa Agropecuária Agrossilvipastoril, 78550-970, CP 343, Sinop, MT, Brasil. E-mail: roberta.carnevalli@embrapa.br. Corresponding author.

\begin{abstract}
Trees in the production systems can effectively reduce hot weather-induced stress in the Brazilian Midwest. High temperatures cause changes in animals daily routine, and trees into pastures can promote benefits. The aim of this research was to evaluate the behavior of dairy heifers in silvopastoral systems in the state of Mato Grosso, Brazil. A herd of 24 crossbreed heifers (3/4 and 7/8 Holstein/Zebu), 350kg average weight, was evaluated over three seasons. Piatã grass was managed under three shade levels: full-sun, moderate-shade, and intensiveshade provided by 10 to $12 \mathrm{~m}$ high Eucalyptus trees. Behavior data were collected every 15 minutes from 8:30h to 16h. Shade availability significantly impacted heifer behavior, mainly affecting grazing frequency and time during the hottest hours. Grazing behavior was affected by shade levels during the different seasons. Heifers showed preferred grazing times. Heifers in the intensive-shade system visited shady areas during the hottest hours throughout the seasons. Heifers in the full sun-system avoided grazing during the warmer times, ceasing feeding activities. Our results from the Brazilian Midwest showed that shade availability causes breed heifers to change their daily routine. Key words: silvopastoral system, Urochloa brizantha, stress, animal behavior.
\end{abstract}

Novilhas leiteiras melhoram sua atividade de pastejo em pastagens tropicais sombreadas

RESUMO: A presença de árvores em sistemas de produção animal pode reduzir o estresse provocado pelo calor no centro-oeste brasileiro. As altas temperaturas induzem a uma mudança na rotina dos animais e, as árvores dentro da pastagem podem promover beneficios. $O$ objetivo desta pesquisa foi avaliar o comportamento de novilhas leiteiras em sistemas integrados no Mato Grosso, Brasil. Um grupo de 24 novilhas cruzadas (3/4 e 5/8 Holandês: Gir) de $350 \mathrm{~kg}$ foi avaliado em três estações do ano. O capim piatã foi manejado sob três níveis de sombreamento: pleno sol e sombreamentos moderado e intenso promovidos por eucaliptos com $12 \mathrm{~m}$ de altura. O comportamento das novilhas foi medido a cada 15 minutos entre 8h30min às 16h. A disponibilidade de sombra modificou o padrão de comportamento das novilhas, afetando a frequência e o tempo de pastejo nas horas mais quentes do dia. O comportamento de pastejo foi afetado pelos níveis de sombra e, variou nas diferentes estações do ano. As novilhas em sistemas com sombreamento intenso procuraram pela sombra nas horas mais quentes do dia durante as três estações do ano avaliadas. Já, as novilhas nas condições de pastagem a pleno sol, não pastejaram durante as horas mais quentes do dia, pois interrompiam suas atividades e permaneciam inativas durante grande periodo do dia. A disponibilidade de sombra induz novilhas cruzadas a mudarem sua rotina diária nas condições do Centro-Oeste brasileiro.

Palavras-chave: sistemas silvopastoril, Urochloa brizantha, estresse, comportamento animal.

\section{INTRODUCTION}

Silvopastoral systems are considered to be a good alternative to improve the animal production, because they reduce temperature-induced stress in animals. As average temperatures in Midwest Brazil are constantly rising, it has become necessary to introduce trees into pasture systems in order to increase the productive and reproductive efficiencies of dairy cows. BLACKSHAW \& BLACKSHAW (1994) claimed that at high temperatures, evaporative cooling is the principal mechanism for heat dissipation in cattle. The responses of a dairy cow to hot weather include reduced feed intake (and therefore, decreased milk production), increased water intake, altered metabolic processes and endocrine status, increased respiratory rate, sweating, and altered body temperature (ARMSTRONG, 1994). NAVARINI et al. (2009) studied beef cattle (nelore) under full sun, in small forest areas, and under isolated trees and recorded body surface temperatures of 35.3, 34.3, and $34.7^{\circ} \mathrm{C}$, respectively. However, in Midwest Brazil, with air temperatures reaching $45^{\circ} \mathrm{C}$ at noon, definite measures need to be incorporated to mitigate these conditions and improve animal productivity (LOPES et al., 2016). To achieve satisfactory results 
in the animal production, factors such as grassland management, forage allowance, and adequate tree population and distribution need to be considered. During hot weather, cattle actively visit the shaded area, which may reduce radiant heat load by $30 \%$ or more (BLACKSHAW \& BLACKSHAW, 1994).

The animals change postures during stress conditions to enhance heat dissipation by wind. They also modify forage intake patterns, including decreased grazing and rumination time, which strongly affects milk production (FERREIRA et al., 2011). Under tropical conditions, with temperatures of up to $40^{\circ} \mathrm{C}$ during the day, animals might largely feed at night. Knowledge regarding dairy heifer production under tropical conditions is still rather limited. Thus, the aim of this research was to evaluate the influence of shade level on dairy heifer behavior in silvopastoral systems during three seasons in the Brazilian Midwest.

\section{MATERIALS AND METHODS}

The experiment was conducted in the Experimental Field of Embrapa Agrossilvipastoril, Sinop, Mato Grosso State, Brazil, 11'51'43'S, $55^{\circ} 35^{\prime} 27^{\prime}$ 'W. Soil type was Oxisol in a flat relief. According to the Köppen classification, the climate is categorized as Aw (tropical climate, rainy summer and dry winter). In 2012 and 2013, annual dry-bulb temperature was $27^{\circ} \mathrm{C}$, with a relative humidity of $76 \%$ and annual rainfall of $2,020 \mathrm{~mm}$ (INMET, 2014) (Figure 1).

The experimental unit measuring 10ha was planted with Piatã grass (Urochloa brizantha, cv. 'Piatã'). One year prior to the experiment, the area had been cultivated with silage corn intercropped with Piatã grass. The experiment comprised three arrangements: (I) total absence of trees in Piatã grass (full-sun system) (2.4ha), (II) presence of peripheral trees along the border fences with Piatã grass (moderate-shade system) (2.6ha), and (III) trees and shrubs intercropped with Piatã grass (intensive-shade system) (4.3ha). The tree ranks were arranged in rows $15 \mathrm{~m}$ apart in an east-west direction. Arrangement was carefully planned to avoid shading of the full-sun and moderate-shade systems. Each system was divided into ten paddocks ( 0.24 to 0.43 ha each, depending on the system), but only three of them were selected for evaluation in each treatment (system). The plantation faced an east-west direction, projecting the shade into the paddocks. Tree planting was undertaken in February 2011; crops and pasture were planted in September 2011. Animal behavior was evaluated from
December 2012 to July 2013, when the trees were two years old and about $12 \mathrm{~m}$ high and the pasture was aged one year. Experiments were undertaken in three periods: Period 1, from February 20 to March 7 (rainy summer season), period 2, from May 6 to 20 (transition rainy-dry season), and period 3, from June 18 to 22 (early part of the dry season, but with forage available for grazing). All paddocks were subjected to nitrogen fertilization of $80 \mathrm{~kg} \mathrm{ha}^{-1}$ year $^{-1}$.

A herd of 24 Brazilian Girolando breed heifers (3/4 and 7/8 -backcrossed to Holstein) was divided into three homogeneous groups regarding live weight and age, with eight test animals evaluated in each arrangement. Each group had four 3/4 and four 7/8 Holstein heifers. Each block (three arrangements each) was evaluated in the same day in every season. Behavior data were collected every $15 \mathrm{~min}$ starting at $08: 30 \mathrm{~h}$ with readings ending at $16: 00 \mathrm{~h}$, using the times of collection of environmental data as reference. The analyzed variables were related to the location: sun exposure or permanence in the shade and to the activity: grazing, walking, and visiting the water point during the day, in three seasons. Three workers (one per block) were trained to observe the animals and recorded their activities. Animal number in each activity was calculated in percentage of each activity every time. In this study, we considered only grazing activity. Evaluations were performed every day. Stocking rate and occupation period were determined by forage allowance. Thus, each heifer was evaluated during its entire time in the enclosure. Heifer quantity within the enclosure was used as variable and manipulated using the put-and-take method (BOVAL \& DIXON, 2012). Water points were located outside for the initial two periods, so the heifers had to pass a gate in order to get access to water. Each system had a gate to ensure that groups remained separate. During the third period, a water point was installed between two enclosures. Although the heifers had access to a water point in the enclosure, they also had full access to the water trough outside.

The fenced areas were geo referenced using the GPS model Garmin ETREX 30. The SMS Advanced from the $\mathrm{Ag}$ Leader program was used to divide the 25 sample grids (TURNER et al., 2000). Grids varied in size according to the principal paddock size. Grids measured 10x10m, 12x10m, and $15 \times 10 \mathrm{~min}$ the full-sun system, moderateand intensive-shade systems, respectively. Air temperature was measured using automatic data acquisition sensors (HOBO data logger; model U12 Temp/RU 2 EXT, Onset ${ }^{\circledR}$ ). To obtain the data in the arrangement with silvopastoral systems, two sensors 
were used in each system: one under the three rows and one midpoint between the rows. Microclimatic measurements were taken from January to July 2013 in 15-min intervals from 08:30 to 16:00. Data set were statistically analyzed using SAS 9.2 (SAS INSTITUTE INC., 2008). Shade level and seasonal effects were tested in terms of grazing time and behavioral activities. Heifer behavior data were also tested. Data normality was tested by the ShapiroWilk test (PROC UNIVARIATE) and variance analyses were performed to verify the main effects and interactions, using PROC MIXED. Average comparison, as necessary, was performed by the PDIFF method with a probability level of $5 \%$.

\section{RESULTS AND DISCUSSION}

\section{Grazing activity}

Shade level significantly impacted several heifer behavior variables, e.g. grazing activity $(\mathrm{P}=0.0001)$. In the rainy season, we recorded the lowest grazing frequency. The full-sun and moderateshade systems were similar with respect to grazing activity; only $21 \%$ of the heifers were grazing in the same time. In the intensive-shade system, $28 \%$ of the heifers showed grazing activity. In the transition period, grazing frequency increased in relation to the rainy season, with the full-sun and moderate-shade systems showing similarity (44\%) in the grazing activity. However, in the intensive-shade system, we observed the highest grazing frequency (56\%) $(\mathrm{P}=0.0001)$. During the transition period, heifer grazing frequency continued to increase. The full-sun and intensive-shade systems showed similar results $(52 \%)$; however, grazing frequency in these systems was lower than in the moderate-shade system (67\%). However, grazing time did not differ between the shade systems ( $3 \mathrm{~h}$ and $18 \mathrm{~min}$, respectively, $42 \%$ of total time). In the rainy season, grazing time was lower ( $2 \mathrm{~h}, 26 \%$ of total time) than in the other seasons ( $4 \mathrm{~h}, 52 \%$ of total time). During the rainy season, grazing time was lower in the full-sun and moderateshade systems (1h and $48 \mathrm{~min}$, respectively, $23 \%$ of total time) than in the intensive-shade system $(2 \mathrm{~h}$ and $36 \mathrm{~h}, 34 \%$ of total time $)(\mathrm{P}=0.0001)$. Early in the dry season, grazing times were similar for the full-sun and moderate-shade systems ( $4 \mathrm{~h}$ and $30 \mathrm{~min}, 58 \%$ of total time), but lower in the intensive-shade system ( $3 \mathrm{~h}$ and $18 \mathrm{~min}, 43 \%$ of total time) $(\mathrm{P}<0.0050)$. The daily variations in grazing activity were different in each system and season (Figure 1). In the rainy season, in the morning, grazing behavior was similar for every shading system, only in the full-sun system, heifers remained grazing until 11:30h (Figure 1A). Heifers under shade conditions reduced grazing activity from 9:00h to $10: 30 \mathrm{~h}$, but there was oscillation until $14 \mathrm{~h}$, with no more than $20 \%$ of the animals grazing after 11:15h. However, the main difference was observed in the afternoon period. In the intensive-shade system, the heifers returned to grazing earlier than in the other systems, in which approximately $80 \%$ of the heifers grazed after $14 \mathrm{~h}$. In the full-sun system, grazing activity was resumed after 15:45h. The moderateshade system was intermediate in terms of heifer behavior, and grazing activity was resumed at 13:45h, similar to the intensive-shade system; however, only $20 \%$ of the heifers resumed grazing. After 15:00h, $50 \%$ of the total heifers resumed grazing.

In the transition period, during the morning, grazing behavior was similar for every system as it occurred during the rainy season; however, grazing stopped at 11:00h in the full-sun system (Figure 1B). At this time, 25 to $30 \%$ of the animals were grazing in the shaded systems. During the afternoon, all heifers $(100 \%)$ resumed grazing at $13: 30 \mathrm{~h}$ in the intensiveshade system, while in the full-sun system, grazing activity was resumed two hours later. Again, the moderate-shade system was intermediate because the heifers resumed grazing at 14:30h (Figure 1b). BETANCOURT et al. (2005), studying Brown Swiss $\mathrm{x}$ Zebu crossbreed cows, showed that the percentage of time spent grazing was higher (44 vs. 35\%) in pastures with a larger tree canopy. Early in the dry season, grazing behavior was similar to that of the other seasons. However, in this season, more heifers resumed grazing at the same time and not gradually, as in the rainy and transition periods (Figure 1C). An exception to this similarity was evident in the full-sun system, where the heifers tried to resume grazing at 12:30h and remained there for an hour, but could not continue, and instead returned after 15:30h, when the temperature was lower.

Maximum temperatures were similar between the periods, despite an increase of $3^{\circ} \mathrm{C}$ at the transition from the rainy to the dry period. However, relative humidity differed between the rainy and the dry season, with values of 88 and $74 \%$, respectively, and rainfall of 400 and $60 \mathrm{~nm}$, respectively (Figure 2). Therefore, despite similar temperatures in the two periods, radiation and rainfall can significantly affect grazing behavior (Figure 2).

In the early part of the dry season, the later return to grazing in the full-sun system was a result of high radiation and not of temperature. In contrast, in the rainy season, high rainfall negatively affected grazing activity. 


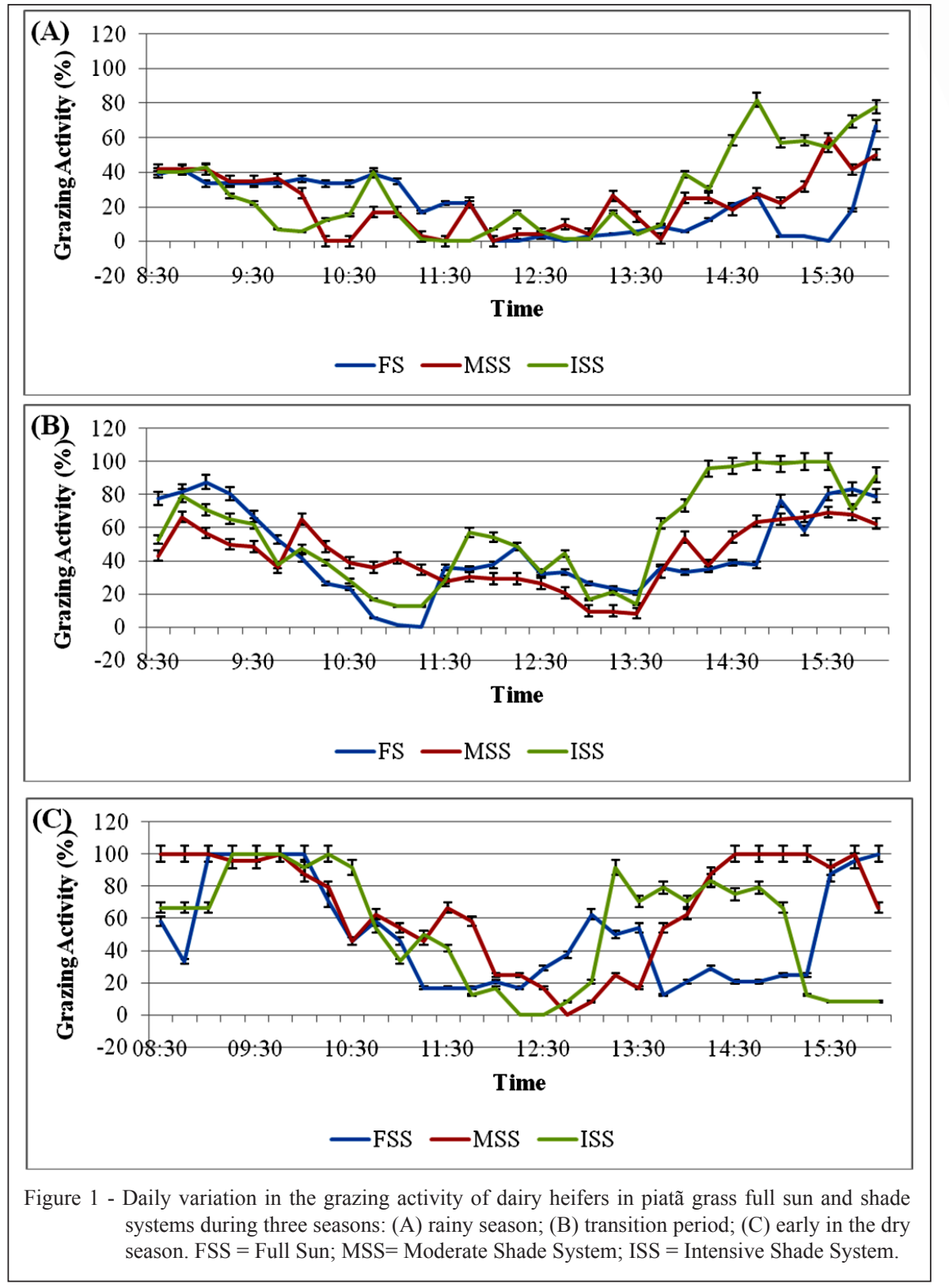

Visits to the water point

A higher number of heifers visited the water trough in the full-sun system $(1.8 \%)$ than in the shade systems $(0.4 \%) \quad(\mathrm{P}=0.0001)$ during the rainy season. Heifers visited the water point more frequently in the full-sun system (ten visits per day) during the transition period; however, each visit occurred in small groups and from 10:00h to $15: 00 \mathrm{~h}$. Visits to the water trough were less frequent in the moderateshade system (nine visits per day) than in the full-sun system $(\mathrm{P}=0.0001)$, but heifer number per visit was higher, reaching $25 \%$ of the total heifers visiting the water trough at 12:15h. Heifers visited water trough earlier in the full-sun system than in the shade systems; however, at 13:45h, heifer number declined. A new visit to the water point occurred at about 16:00h. In the intensive-shade system, the frequency of the visits to the water points was lower $(1.3 \%)$, which could be an indication that heifers had visited water point to assuage their body heat and not necessarily to drink. SCHUTZ et al. (2010) observed that cows lingered around the water trough when shade was not available. The behavior was similar to that of the other seasons in the early part of the dry season. The time in which each activity occurred changed, so the visits to the trough in this season occurred from $10: 15 \mathrm{~h}$ to $15: 30 \mathrm{~h}$ 


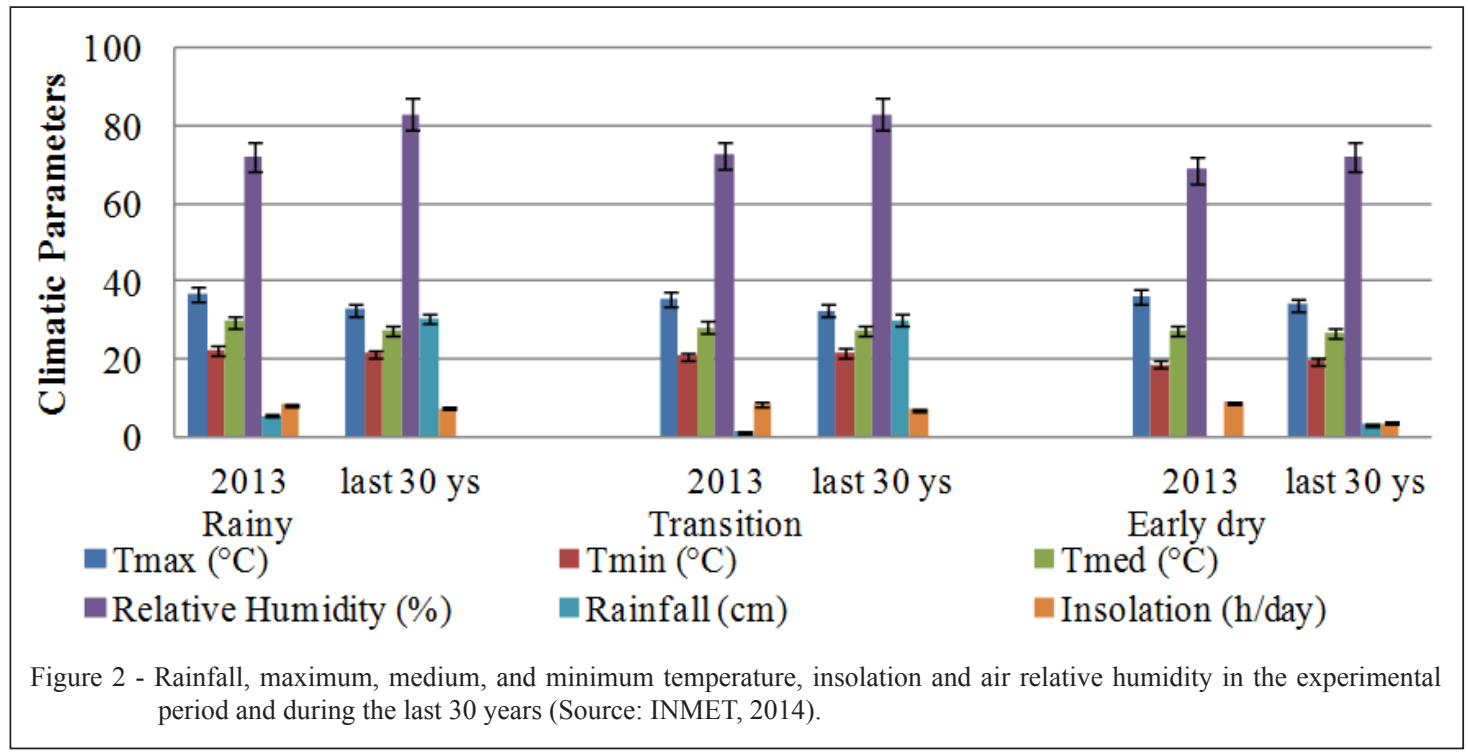

$(\mathrm{P}=0.0001)$. The time spent drinking was longer in the full-sun system ( $7 \mathrm{~min}, 1.7 \%$ total time) than in the shade systems (4 min, 1\% total time).Our results are in agreement with those reported in a similar study on sheep in Australia. The authors reported that Merino sheep in pastures visit the water point once a day in the early part of the summer and twice a day in late summer. The volume of water consumed varied from 2.3 $\mathrm{L} \mathrm{day}^{-1}$ in December to $9.3 \mathrm{~L} \mathrm{day}^{-1}$ in March; average daily distance walked was $4.7 \mathrm{~km}$ day $^{-1}$, with a peak of $6.2 \mathrm{~km} \mathrm{day}^{-1}$ in the late summer when the forage on offer dropped to low levels (SHERWIN \& JOHNSON, 1987). In our study, shade reduced the time spent visiting the water point during the day. This fact can be attributed to the fact that the animals visit the water point to cool down rather than to actually drink. In a previous study from the temperature zone, SCHUTZ et al. (2010) observed that the time spent near water increased when little or no shade was available.

\section{Locomotion activity}

In the rainy season, $5.6 \%$ of the total heifers were walking, while early in the dry season, only $4.5 \%$ continued this activity $(\mathrm{P}=0.0001)$. This frequency was $7.5 \%$ of the total heifers, on average, in the transition period. Heifers walked more $(8.5 \%$ of the total heifers) in the moderate-shade system than in other systems during the rainy season $(4.1 \%$ of the total heifers $)(\mathrm{P}=0.0001)$. In the full-sun system, more heifers walked $(9.7 \%)$ than in the other systems during the transition period $(6.4 \%)$ $(\mathrm{P}=0.0037)$. However, no difference was reported $(4.5 \%)$ during the early part of the dry season, when the water troughs were located inside the enclosures $(\mathrm{P}=0.8227)$. The average time spent walking was $27 \mathrm{~min}$ per day, independent of the system. According to COOK et al. (2007), locomotion score is higher in the warmer than in the colder months, suggesting that cattle exposed to higher temperatures are more likely to stand to improve heat dissipation.

\section{Visits to the shaded areas}

In the systems where shade was available, $70 \%$ of all heifers visited shady areas during the rainy period. In the transition period, heifer frequency in the shade was higher in the intensive-shade system $(63.5 \%)$ than in the moderate-shade system $(57.5 \%)$ ( $\mathrm{P}=0.0001)$. FERREIRA et al. (2014) evaluated behavioral responses of crossbreed dairy cattle in the Brazilian Midwest submitted to different shade availability and noticed that animals spent up to $57 \%$ of their time in the paddocks under the shade. In another study, ATRIAN \& SHAHRYAR (2012) also reported that the time spent in the shade was proportional to the air temperature. The most preferred time for staying in the shade was from $09: 45 \mathrm{~h}$ to noon in the intensive-shade system $(\mathrm{P}=0.0001)$. Early in the dry season, $84 \%$ of the total heifers preferred the shaded area in the intensive-shade system, while in the moderate-shade system, only $39 \%$ of the total heifers were in the shade. During the early part of the dry season, almost the entire area in the intensive-shade system was shaded; therefore, the rarely spent time in the sun. KARKI \& GOODMAN (2010) reported that grazing was the dominant activity in silvopastoral systems, while idleness was the major behavior 
in open pastures. These behavioral differences occurred mainly because of consistent variation in microclimatic conditions between systems. Results from TUCKER et al. (2008) demonstrated that the degree of protection from solar radiation is an important design feature of effective shade for dairy cattle. Cows were more likely to use the shade structures when ambient solar radiation levels were at their highest during the day, highlighting the importance of providing enough shade, as all the cows simultaneously use this resource. When shade was available, heifers visited it in the warmer periods of the day. When shade was unavailable, they stopped and did not graze for a long time. In a similar study in the tropics BENNET et al. (1985) could show that in steers, the amount of time spent in the shade was closely correlated with the amount of time spent grazing. Therefore, as heifers visit the shaded area on the warmer days for their routine activities, it is necessary to provide adequate levels of shade in grasslands.

\section{CONCLUSION}

The silvopastoral system containing Piatã grass and intensive shade negatively affects sward structure and positively impacts heifer grazing behavior. In the Brazilian Midwest, the high daily temperature induces higher dependency on shaded grassland, affecting the animals' daily routine. Heifers under the full sun avoid grazing during the warmer times; they cease their activities. Our results showed the importance of providing at least moderate shade for heifers on pastures.

\section{BIOETHICS AND BIOSSECURITY COMMITTEE APPROVAL}

Statement of animal rights: The authors certify that no willful act of abuse, cruelty, or neglect of animal rights have occurred. The Ethics Committee for Animal Use of Embrapa Agrosilvopastoral, Sinop-Mato Grosso state, Brazil, has approved the study under the number $001 / 2015$.

\section{ACKNOWLEDGEMENTS}

This Project was financed by Conselho Nacional de Desenvolvimento Científico e Tecnológico (CNPq), Empresa Brasileira de Pesquisa Agropecuária (Embrapa) and Coordenação de Aperfeiçoamento de Pessoal de Nível Superior (Capes).

\section{REFERENCES}

ARMSTRONG, D.V. Heat stress interaction with shade and cooling. Journal of Dairy Science, v.77, p.2044-2050,
1994. Available from: <http://dx.doi.org/10.3168/jds.S00220302(94)77149-6>. Accessed: Dec. 8, 2015. doi: 10.3168/jds. S0022-0302(94)77149-6.

ATRIAN, P.; SHAHYAR, H.A. Heat stress in dairy cows (a review). Research in Zoology, v.2, p.31-37, 2012. Available from: $<$ http://article.sapub.org/pdf/10.5923.j.zoology.20120204.03.pdf>. Acessed: Nov. 17, 2015. doi: 10.5923/j.zoology.20120204.03.

BENNET, I.L. et al. Time spent in shade and its relationship with physiological factors of thermoregulation in three breed of cattle. Applied Animal Behaviour Science, v.13, p.227-236, 1985. Available from: <http://dx.doi.org/10.1016/0168-1591(85)900462>. Accessed: Oct. 25, 2015. doi:10.1016/0168-1591(85)90046-2.

BETANCOURT, K. et al. Effect of tree cover on animal behavior in dual-purpose cattle farms in Matiguas, Matagalpa, Nicaragua. Agroforesteria en las Américas, v.10, p.47-51, 2005. Available from: <https://www.researchgate.net/publication/239931834_ Efecto de la cobertura arborea sobre el_comportamiento animal_en_fincas_ganaderas_de_doble_proposito_en_Matiguas_Matagalpa_Nicaragua $>$. Accessed: Jan. 15, $201 \overline{6}$. ISSN $102 \overline{2}-7482$.

BLACKSHAW, J.K.; BLACKSHAW, A.W. Heat stress in cattle and the effect of shade on production and behaviour: a review. Australian Journal of Experimental Agriculture, v.34, n.2, p.285-295, 1994. Available from: <http://dx.doi.org/10.1071/ EA9940285>. Accessed: Nov. 05, 2015. doi:10.1071/EA9940285.

BOVAL, M.; DIXON, R.M. The importance of grasslands for animal production and other functions: a review on management and methodological progress in the tropics. Animal, v.6, p.748-762, 2012. Available from: <https://www.researchgate. net/publication/224911527_The_importance_of_grasslands_ for_animal_production_and_other_functions_A_review_on_management_and_methodological_progress_in_the tropics $>$. Accessed: Oct. 25, 2015. doi:10.1017/S1751731112000304.

COOK, N.B. et al. The effect of heat stress and lameness on time budgets of lactating dairy cows. Journal Dairy Science, v.90, p.1674-1682, 2007. Available from: <https://www.researchgate. net/publication/6438655_The_Effect_of_Heat_Stress_and_ Lameness_on_Time_Budgets_of Lactating_Dairy_Cows $>$. Accessed: $\bar{N}$ ov. $\overline{0} 5,2015$. doi: $10 . \overline{3} 16 \overline{8} /$ jds.2006-634

FERREIRA, L.C.B. et al. The effect of different offers shading in the dispersion of the feces of cattle in the pasture. Revista Brasileira de Agroecologia, v.6, n.1, p.137-146, 2011. Available from: <http://orgprints.org/23308/1/Ferreira_Efeito. pdf>. Accessed: Dec. 08, 2015. ISSN: 1980-9735.

FERREIRA, L.C.B. et al. Respostas fisiológicas e comportamentais de bovinos submetidos a diferentes ofertas de sombra. Cadernos de Agroecologia, v.9, n.2, p.1-14, 2014 (in Portuguese). Available from: <http://www.aba-agroecologia. org.br/revistas/index.php/cad/article/viewFile/15843/10019>. Accessed: Dec. 08, 2015. ISSN 2236-7934

INMET, 2014. Ministério da Agricultura, Pecuária e Abastecimento. Available from: <http://www.inmet.gov.br/ portal/index.php?r=home/page\&page=rede_estacoes_auto_graf $>$. Online. Accessed: Oct. 25, 2015.

KARKI, U.; GOODMAN, M.S. Cattle distribution and behavior in southern-pine silvopasture versus open-pasture. Agroforestry 
Systems, v.78, p.159-168, 2010. Available from: <http://link. springer.com/article/10.1007/s10457-009-9250-x>. Accessed: Dec. 08, 2015. doi:10.1007/s10457-009-9250-x.

LOPES, L.B. et al.The influence of trees on the thermal environment and behaviour of grazing heifers in Brazilian Midwest. Tropical Animal Health Production, v.48, n.4, p.755-761, 2016. Available from: <http://link.springer.com/article/10.1007/s11250-016-1021-x>. Accessed: Feb. 19, 2016.doi: 10.1007/s11250-016-1021-x.

NAVARINI, F.C. et al. Conforto térmico de bovinos da raça nelore a pasto sob diferentes condições de sombreamento e a pleno sol. Engenharia Agrícola, Jaboticabal, v.29, n.4, p.508-517, 2009. Available from: $<\mathrm{http}$ //www.scielo.br/scielo.php?script=sci arttext\&pid=S0100-69162009000400001\&lng=en\&nrm=iso> Accessed: Oct. 25, 2015. doi: 10.1590/S0100-69162009000400001.

SAS INSTITUTE. SAS Software Version 9.2. Cary, NC, 2008 Version 9.2.

SCHUTZ, K.E et al. The amount of shade influences the behavior and physiology of dairy cattle. Journal of Dairy Science, v.93, p.125-133, 2010. Available from: <https://www.ncbi.nlm.nih. gov/pubmed/20059911>. Accessed: Nov. 13, 2015. doi:10.3168/ jds.2009-2416

SHERWIN, C.W.; JOHNSON, K.G. The influence of social factors on the use of shade by sheep. Applied, v.18, n.2, p.143-155, 1987. Available from: <http://dx.doi.org/10.1016/0168-1591(87)901882>. Accessed: Oct. 25, 2015. doi:10.1016/0168-1591(87)90188-2.

TUCKER, C.B. et al. Effect of solar radiation on dairy cattle behaviour, use of shade and body temperature in a pasture-based system. Applied Animal Behaviour Science, v.109, n.2-4, p.141-154, 2008. <http://dx.doi.org/10.1016/j. applanim.2007.03.015>. Accessed: Oct. 25, 2015. doi: 10.1016/j.applanim.2007.03.015

TURNER, L.W et al. Monitoring cattle behavior and pasture use with GPS and GIS. Canadian Journal of Animal Science, v.80, n.3, p.405-413, 2000. Available from: <https://www.researchgate. net/publication/250380195_Monitoring_cattle_behavior_and pasture_use_with_GPS_and_GIS $>$. Accessed: Oct. 25, 2015. doi: $10 . \overline{4} 141 /$ A99-093. 